\title{
エネルギー論に基づくシールドトンネルの安定解析 STABILITY OF SHIELD DRIVEN TUNNEL BY ENERGETICS
}

\author{
松 本 嘉 司*・西岡隆**・佐野可寸志*** \\ By Yoshiji MATSUMOTO, Takashi NISHIOKA and Kazushi SANO
}

\begin{abstract}
Shield tunneling is used in the construction of life-line systems in urban area. Its technology has rapidly been developed but the theoretical background does not have been established yet.

Stress and displacement in linings are studied by stress function of polar coordinate, and the stability of ground is also analyzed by distortional strain energy both in unsaturated and saturated condition. The analysis shows that the distortional strain energy is the good index for supporting mechanism of shield driven tunnel.

Keywords : shield tunneling, tunnel lining, distortional strain energy, saturated ground
\end{abstract}

\section{1.はじめに}

都市の狭あい化につれて, 都市内のトンネル施工は シールド工法が多く用いられるようになった. シールド トンネルの特徴はシールド機によって地山を掘削すると ともに，その後方にあらかじめ工場で製作されたセグメ ントを組み立てて, 覆工することにある. 最近では, さ らに場所打ちコンクリートを押し出して覆工する試みも 行われようとしている. シールドトンネルの施工技術の 発展はめざましいものがあり, 問題解決のための新たな 手法が次々と開発されてきている. 適切な圧力でシール ド機の背後に裏込め材を注入するとか, トンネルのライ ニングに押出しコンクリートを用いることによって, 従 来シールドトンネルの欠点とされてきた地山とライニン グ間の空陌がなくなれば，力学理論に基づいた合理的な トンネルを構築することが可能になる.

先に著者らは吹付けコンクリートとロックボルトで支 保されたトンネルの安定性が, 地山が蓄えることができ

* 正会員 工博 東京理科大学教授 理工学部土木工学科 （テ278 野田市山崎 2641）

** 正会員 工博 筑波大学教授 構造工学系 （３05 つくば市天王台 1-1)

*** 正会員 工修 東京大学助手 工学部土木工学科 ( T113 文京区本郷 7-3-1)
る最大形状弾性ひずみエネルギーと, 掘削によって地山 に発生する形状弾性ひずみエネルギーの大小関係から判 定できることを示した1).

さらにこの理論を現実のトンネル計測結果に適用し， トンネル施工の安全率を提案するとともに ${ }^{2)}$, 比較的土 被りの浅いトンネルでは重力の影響を無視できないこと を指摘した ${ }^{3)}$. 本論文はこれらの結果をさらにシールド トンネルに適用し, シールドトンネルの力学的性状とそ の周辺地山の安定性, 地下水の影響などを考慮して検討 したものである.なお，解析的に取り扱った理論として， 参考文献 7) 9）があるが，これらは素掘りの状態での 解析にとよ゙まっており, 地山の安定性にまで言及してい ない.

\section{2. トンネル周辺の地山とトンネル・ライニン グの応力}

トンネルの断面を図一1 に示すようにモデル化する. ここで $t$ はトンネル・ライニングの厚さ, $r_{0}, r_{1}$ はそ れぞれトンネル・ライニングの外径と内径, $E_{R}, \nu_{R}, E_{c}$, $\nu_{c}$ はそれぞれ地山およびライニングコンクリートのヤ ング係数, ポアソン比である. また地表からトンネル中 心までの深度を $h$, 土被りを $H$, 重力の加速度を $g$, 地山およびライニングの単位体積重量をそれぞれ $\rho, \rho^{\prime}$ 


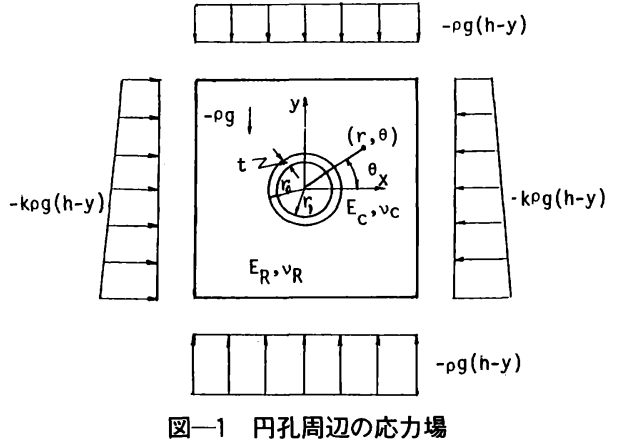

にとる.

解析にあたって以下の仮定を設ける.

1）破壊に至るまでは地山は弾性的に挙動するものと する.

シールドトンネルの理想的な施工は地山を緩めないこ とである. シールド工法では，泥水や泥土を切羽全面の 土圧に均衡させて掘削するとともに，セグメントと周辺 地山との間を完全に密着させるために，シールド機の背 面に裏込妵入材を充填するとか，場所打ちコンクリー トをトンネル・ライニングに用いる．このような場合に は，ライニング亡地山の間に空陌は存在しないものと考 えられ，地山は破壊に至るまではほぼ弾性的に挙動する ものと仮定する.

2）トンネル・ライニングに作用する地山の応力のう ち, 直応力はライニングに伝達されるが, せん断応力は 伝達されないものとする.

掘削後セグメント背面に空隙が存在しない限り, 地山 に発生する半径方向の変位はライニングによって拘束さ れ, その結果地山に発生する直応力はライニングに伝達 される. しかし，掘削によっていったん解放された地山 の周方向の変位をライニングによって拘束したり，せん 断応力をライニングに担わせることは不可能である.し たがって, ライニングの背面, あるいはトンネルと地山 の境界ではせん断応力は 0 であると仮定する.

3） ライニングはコンクリート製の剛性一様で均一な 厚さをもつ円筒状であると仮定する.

本研究は地山の特性に対する断面力の変化や地山の安 定性を検討することを主な目的としているため, リング 継手やセグメント継手の効率はここでは考えない，セグ メントの材質や継手の剛性低下は, 必要に応じてライニ ングの弾性係数 $E_{c}$ の低減あるいはライニングの厚さ $t$ の調整によって補正すればよい，以下の計算例ではライ ニングの弾性係数, 厚さとして, 半径 $5 \mathrm{~m}$ の円形シー ルドトンネルに対して, それぞれ $E_{c}=2.4 \times 10^{5} \mathrm{~kg} / \mathrm{cm}^{2}$

(23. $5 \mathrm{GPa}), \quad t=30 \mathrm{~cm}$ を標準の值にとっている.

4）比較的土被りは浅いものとし，地山には重力が作
用するものとする.

シールドトンネルのように土被りの浅いトンネルで は，地山に作用する重力の影響を無視することはできな (3). 特に, 土被り厚がトンネル半径のおよそ 2 倍程度 までは重力の影響が大きい，そこで，ここでは境界で囲 まれた全領域には, 物体力として単位体積当たりー $\rho g$ の重力が作用しているものとする．地表面からトンネル 中心までの距離を $h$ にとれば，無限遠での鉛直圧縮応 力は- $\rho g(h-y)$, 水平圧縮応力は- $k \rho g(h-y)$ で表 わすことができる.ここで $k$ は側圧係数である.

以上のような仮定のもとに，地山とライニングを平面 ひずみ場における二次元弾性問題と考え, 地山とライ二 ングに発生する応力と変位を解析的に求めた.

極座標表示による応力場は, 以下のように与えられる.

$$
\begin{aligned}
& \sigma_{r r}=\frac{1}{r} \frac{\partial \phi}{\partial r}+\frac{1}{r^{2}} \frac{\partial^{2} \phi}{\partial \theta^{2}}+\rho g r \sin ^{3} \theta \\
& \sigma_{\theta \theta}=\frac{\partial^{2} \phi}{\partial r^{2}}+\rho g r \sin \theta \cos ^{2} \theta \\
& \sigma_{r \theta}=-\frac{\partial}{\partial r}\left(\frac{1}{r} \frac{\partial \phi}{\partial \theta}\right)+\rho g r \cos \theta \sin ^{2} \theta
\end{aligned}
$$

ここで, $\sigma_{r r}$ は半径方向応力, $\sigma_{\theta \theta}$ は周方向応力, $\sigma_{r \theta}$ は せん断応力である. また $\phi$ は Airy の応力関数であり, $y$ 軸に関して対称であるときには以下のように与えられ る.

$$
\begin{aligned}
\phi= & a_{0}+b_{0} \ln r+c_{0} r^{2}+A_{0} \theta \\
& +\left(b_{1} r \ln r+\frac{c_{1}}{r}+d_{1} r^{2}\right) \sin \theta+A_{1} r \theta \cos \theta \\
& +\sum_{n=2}^{\infty}\left(a_{n} r^{n}+b_{n} r^{2+n}+c_{n} r^{-n}+d_{n} r^{2-n}\right)_{\cos n \theta}^{\sin n \theta}
\end{aligned}
$$

半径方向ひずみ $\varepsilon_{r r}$, 周方向ひずみ $\varepsilon_{\theta \theta}$, せん断ひずみ $\varepsilon_{r \theta}$, 半径方向変位 $u_{r}$, 周方向変位 $u_{\theta}$ と上記の応力之 の間には次の関係がある.

$$
\begin{aligned}
& \varepsilon_{r r}=\left(\sigma_{r r}-\nu_{0} \sigma_{\theta \theta}\right) / E_{0} \\
& \varepsilon_{\theta \theta}=\left(\sigma_{\theta \theta}-\nu_{0} \sigma_{r r}\right) / E_{0} \\
& \varepsilon_{r \theta}=\sigma_{r \theta} / 2 G=\left(1+\nu_{0}\right) \sigma_{r \theta} / E_{0} \\
& u_{r}=\int \varepsilon_{r r} d r \\
& u_{\theta}=\int\left(r \varepsilon_{\theta \theta}-u_{r}\right) d \theta
\end{aligned}
$$

ただし， $E_{0}, \nu_{0}$ はそれぞれ平面ひずみ状態においては 以下の値をとる.

$$
E_{0}=E /\left(1-\nu^{2}\right), \quad \nu_{0}=\nu /(1-\nu)
$$

したがって, 地山の応力 $\sigma_{r r}^{R}, \sigma_{\theta \theta}^{R}, \sigma_{r \theta}^{R}$ および変位 $u_{r}^{R}$, $u_{\theta}^{R}$ は次式で与えられる. ここで, 上付きの添字 $R$ は地 山を表わしている.

$$
\sigma_{r r}^{R}=\frac{b_{0}}{r^{2}}+2 c_{0}+\left(\frac{b_{1}}{r}-\frac{2 c_{1}}{r^{3}}+2 d_{1} r-\frac{2 A_{1}}{r}+\frac{3}{4} \rho g r\right)
$$


$\cdot \sin \theta-\left(2 a_{2}+\frac{6 c_{2}}{r^{4}}+\frac{4 d_{2}}{r^{2}}\right) \cos 2 \theta$

$-\left(6 a_{3} r+4 b_{3} r^{3}+\frac{12 c_{3}}{r^{5}}+\frac{10 d_{3}}{r^{3}}+\frac{1}{4} \rho g r\right)$

$\cdot \sin 3 \theta$

$\sigma_{\theta \theta}^{R}=-\frac{b_{0}}{r^{2}}+2 c_{0}+\left(\frac{b_{1}}{r}+\frac{2 c_{1}}{r^{3}}+6 d_{1} r+\frac{1}{4} \rho g r\right) \sin \theta$

$+\left(2 a_{2}+12 b_{2} r^{2}+\frac{6 c_{2}}{r^{4}}\right) \cos 2 \theta$

$+\left(6 a_{3} r+20 b_{3} r^{3}+\frac{12 c_{3}}{r^{5}}+\frac{2 d_{3}}{r^{3}}+\frac{1}{4} \rho g r\right)$

$\cdot \sin 3 \theta$

$\sigma_{r \theta}^{R}=\frac{A_{0}}{r^{2}}+\left(-\frac{b_{1}}{r}+\frac{2 c_{1}}{r^{3}}-2 d_{1} r+\frac{1}{4} \rho g r\right) \cos \theta$

$+\left(2 a_{2}+6 b_{2} r^{2}-\frac{6 c_{2}}{r^{4}}-\frac{2 d_{2}}{r^{2}}\right) \sin 2 \theta$

$-\left(6 a_{3} r+12 b_{3} r^{3}-\frac{12 c_{3}}{r^{5}}-\frac{6 d_{3}}{r^{3}}+\frac{1}{4} \rho g r\right)$

$\cdot \cos 3 \theta$

$u_{r}^{R}=\frac{1}{E_{0}^{R}}\left[-\frac{b_{0}}{r}\left(1+\nu_{0}^{R}\right)+2 c_{0}\left(1-\nu_{0}^{R}\right) r\right.$

$+\left\{b_{1}\left(1-\nu_{0}^{R}\right) \ln r+\frac{c_{1}}{r^{2}}\left(1+\nu_{0}^{R}\right)+d_{1}\left(1-3 \nu_{0}^{R}\right) r^{2}\right.$

$\left.-2 A_{1} \ln r+\frac{1}{8} \rho g r^{2}\left(3-\nu_{0}^{R}\right)\right\} \sin \theta$

$+\left\{-2 a_{2}\left(\nu_{0}^{R}+1\right) r-4 b_{2} \nu_{0}^{R} r^{3}+\frac{2 c_{2}\left(\nu_{0}^{R}+1\right)}{r^{3}}\right.$

$\left.+\frac{4 d_{2}}{r}\right\} \cos 2 \theta+\left\{-3 a_{3}\left(\nu_{0}^{R}+1\right) r^{2}\right.$

$-b_{3}\left(5 \nu_{0}^{R}+1\right) r^{4}+\frac{3 c_{3}\left(\nu_{0}^{R}+1\right)}{r^{4}}+\frac{d_{3}\left(\nu_{0}^{R}+5\right)}{r^{2}}$

$\left.\left.-\frac{1}{8} \rho g r^{2}\left(\nu_{0}^{R}+1\right)\right\} \sin 3 \theta\right]-S_{2} \sin \theta$

$u_{\theta}^{R}=\frac{1}{E_{0}^{R}}\left[-\left\{b_{1}\left(1-\nu_{0}^{R}\right)(1-\ln r)+\frac{c_{1}\left(1+\nu_{0}^{R}\right)}{r^{2}}\right.\right.$

$+d_{1}\left(5+\nu_{0}^{R}\right) r^{2}+2 A_{1}\left(\ln r+\nu_{0}^{R}\right)$

$\left.-\frac{1}{8} \rho g r^{2}\left(5 \nu_{0}^{R}+1\right)\right\} \cos \theta+\left\{2 a_{2}\left(\nu_{0}^{R}+1\right) r\right.$

$\left.+2 b_{2}\left(\nu_{0}^{R}+3\right) r^{3}+\frac{2 c_{2}\left(\nu_{0}^{R}+1\right)}{r^{3}}+\frac{2 d_{2}\left(\nu_{0}^{R}-1\right)}{r}\right\}$

$\cdot \sin 2 \theta-\left\{3 a_{3}\left(\nu_{0}^{R}+1\right) r^{2}+b_{3}\left(3 \nu_{0}^{R}+7\right) r^{4}\right.$

$\left.+\frac{3 c_{3}\left(\nu_{0}^{R}+1\right)}{r^{4}}+\frac{d_{3}\left(3 \nu_{0}^{R}-1\right)}{r^{2}}+\frac{1}{8} \rho g r^{2}\left(\nu_{0}^{R}+1\right)\right\}$

$\cdot \cos 3 \theta]+S_{2} \sin \theta$

一方コンクリートライニングに作用する半径方向応力 $\sigma_{r r}^{c}$, 周方向応力 $\sigma_{\theta \theta}^{c}$, 世ん断応力 $\sigma_{r \theta}^{c}$, 半径方向変位 $u_{r}^{c}$,
周方向変位 $u_{\theta}^{c}$ は, 一般形で表わせば,

$$
\begin{aligned}
\sigma_{r r}^{c}= & \frac{b_{0}^{\prime}}{r^{2}}+2 c_{0}^{\prime}+\left(\frac{b_{1}^{\prime}}{r}-\frac{2 c_{1}^{\prime}}{r^{3}}+2 d_{1}^{\prime} r-\frac{2 A_{1}^{\prime}}{r}+\frac{3}{4} \rho^{\prime} g r\right) \\
& \cdot \sin \theta-\left(2 a_{2}^{\prime}+\frac{6 c_{2}^{\prime}}{r^{4}}+\frac{4 d_{2}^{\prime}}{r^{2}}\right) \cos 2 \theta \\
& -\left(6 a_{3}^{\prime} r+4 b_{3}^{\prime} r^{3}+\frac{12 c_{3}^{\prime}}{r^{5}}+\frac{10 d_{3}^{\prime}}{r^{3}}+\frac{1}{4} \rho^{\prime} g r\right) \\
& \cdot \sin 3 \theta \\
\sigma_{\theta \theta}^{c}= & -\frac{b_{0}^{\prime}}{r^{2}}+2 c_{0}^{\prime}+\left(\frac{b_{1}^{\prime}}{r}+\frac{2 c_{1}^{\prime}}{r^{3}}+6 d_{1}^{\prime} r+\frac{1}{4} \rho^{\prime} g r\right) \sin \theta \\
& +\left(2 a_{2}^{\prime}+12 b_{2}^{\prime} r_{2}+\frac{6 c_{2}^{\prime}}{r^{4}}\right) \cos 2 \theta \\
& +\left(6 a_{3}^{\prime} r+20 b_{3}^{\prime} r^{3}+\frac{12 c_{3}^{\prime}}{r^{5}}+\frac{2 d_{3}^{\prime}}{r^{3}}+\frac{1}{4} \rho^{\prime} g r\right)
\end{aligned}
$$

$\cdot \sin 3 \theta$

$\sigma_{r \theta}^{c}=\frac{A_{0}^{\prime}}{r^{2}}+\left(-\frac{b_{1}^{\prime}}{r}+\frac{2 c_{1}^{\prime}}{r^{3}}-2 d_{1}^{\prime} r+\frac{1}{4} \rho^{\prime} g r\right) \cos \theta$

$+\left(2 a_{2}^{\prime}+6 b_{2}^{\prime} r^{2}-\frac{6 c_{2}^{\prime}}{r^{4}}-\frac{2 d_{2}^{\prime}}{r^{2}}\right) \sin 2 \theta$

$-\left(6 a_{3}^{\prime} r+12 b_{3}^{\prime} r^{3}-\frac{12 c_{3}^{\prime}}{r^{5}}-\frac{6 d_{3}^{\prime}}{r^{3}}+\frac{1}{4} \rho^{\prime} g r\right)$

$\cdot \cos 3 \theta$

$u_{r}^{c}=\frac{1}{E_{0}^{c}}\left[-\frac{b_{0}^{\prime}}{r}\left(1+\nu_{0}^{c}\right)+2 c_{0}^{\prime}\left(1-\nu_{0}^{c}\right) r\right.$

$+\left\{b_{1}^{\prime}\left(1-\nu_{0}^{c}\right) \ln r+\frac{c_{1}^{\prime}}{r^{2}}\left(1+\nu_{0}^{c}\right)+d_{1}^{\prime}\left(1-3 \nu_{0}^{c}\right) r^{2}\right.$

$\left.-2 A_{1}^{\prime} \ln r+\frac{1}{8} \rho^{\prime} g r^{2}\left(3-\nu_{0}^{c}\right)\right\} \sin \theta$

$+\left\{-2 a_{2}^{\prime}\left(\nu_{0}^{c}+1\right) r-4 b_{2}^{\prime} \nu_{0}^{c} r^{3}\right.$

$\left.+\frac{2 c_{2}^{\prime}\left(\nu_{0}^{c}+1\right)}{r^{3}}+\frac{4 d_{2}^{\prime}}{r}\right\} \cos 2 \theta$

$+\left\{-3 a_{3}^{\prime}\left(\nu_{0}^{c}+1\right) r^{2}-b_{3}^{\prime}\left(5 \nu_{0}^{c}+1\right) r^{4}+\frac{3 c_{3}^{\prime}\left(\nu_{0}^{c}+1\right)}{r^{4}}\right.$

$\left.\left.+\frac{d_{3}^{\prime}\left(\nu_{0}^{c}+5\right)}{r^{2}}-\frac{1}{8} \rho^{\prime} g r^{2}\left(\nu_{0}^{c}+1\right)\right\} \sin 3 \theta\right]$

$-S_{2} \sin \theta$

$u_{\theta}^{c}=\frac{1}{E_{0}^{c}}\left[-\left\{b_{1}^{\prime}\left(1-\nu_{0}^{c}\right)(1-\ln r)+\frac{c_{1}^{\prime}\left(1+\nu_{0}^{c}\right)}{r^{2}}\right.\right.$

$\left.+d_{1}^{\prime}\left(5+\nu_{0}^{c}\right) r^{2}+2 A_{1}^{\prime}\left(\ln r+\nu_{0}^{c}\right)-\frac{1}{8} \rho^{\prime} g r^{2}\left(5 \nu_{0}^{c}+1\right)\right\}$

$\cdot \cos \theta+\left\{2 a_{2}^{\prime}\left(\nu_{0}^{c}+1\right) r+2 b_{2}^{\prime}\left(\nu_{0}^{c}+3\right) r^{3}\right.$

$\left.+\frac{2 c_{2}\left(\nu_{0}^{c}+1\right)}{r^{3}}+\frac{2 d_{2}^{\prime}\left(\nu_{0}^{c}-1\right)}{r}\right\} \sin 2 \theta$

$-\left\{3 a_{3}^{\prime}\left(\nu_{0}^{c}+1\right) r^{2}+b_{3}^{\prime}\left(3 \nu_{0}^{c}+7\right) r^{4}+\frac{3 c_{3}^{\prime}\left(\nu_{0}^{c}+1\right)}{r^{4}}\right.$

$\left.\left.+\frac{d_{3}^{\prime}\left(3 \nu_{0}^{c}-1\right)}{r^{2}}+\frac{1}{8} \rho^{\prime} g r^{2}\left(\nu_{0}^{c}+1\right)\right\} \cos 3 \theta\right]$

となる.ここで $E_{0}^{c}, \nu_{0}^{c}, \rho^{\prime}$ はそれぞれコンクリートの 
ヤング係数, ポアンン比および単位重量である.

ライニングと地山の境界条件は次式で表わすことがで きる.

(1) $\sigma_{r r}^{c}\left(r_{1}\right)=0$

(2) $\sigma_{r \theta}^{c}\left(r_{1}\right)=0$

(3) $\sigma_{r r}^{c}\left(r_{0}\right)=\sigma_{r r}^{R}\left(r_{0}\right)$

(4) $\sigma_{r \theta}^{c}\left(r_{0}\right)=0$

(5) $\sigma_{r \theta}^{R}\left(r_{0}\right)=0$

(6) $u_{r}^{c}\left(r_{0}\right)=u_{r}^{R}\left(r_{0}\right)$

ここで(1)(2)はライニング内壁での境界条件を，(3)～(6) は外壁での境界条件を与えている．またトンネルから十 分離れた位置 $(r \rightarrow \infty)$ では以下の関係が成り立ってい る。

$$
\begin{aligned}
& \sigma_{x x}=-k \rho g(h-r \sin \theta), \sigma_{y y}=-\rho(h-r \sin \theta), \\
& \sigma_{x y}=0
\end{aligned}
$$

これらの境界条件から末定係数を求めると, それらは以 下のようになる.ただし， $X=r_{1} / r_{0}$ とおいている.

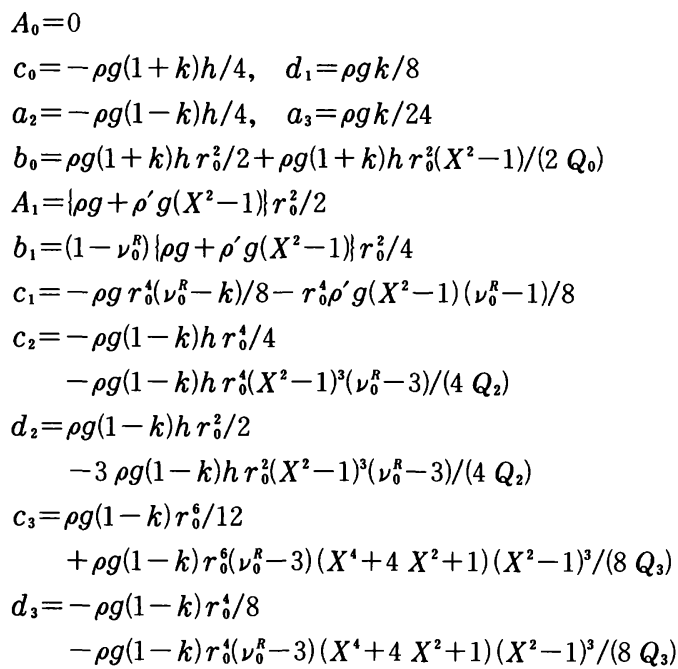

一方シールドリングの係数は,

$A_{0}^{\prime}=0$

$b_{0}^{\prime}=\rho g(1+k)\left(\nu_{0}^{R}+1\right) h r_{0}^{2} X^{2} /\left(2 Q_{0}\right)$

$c_{0}^{\prime}=-\rho g(1+k) h\left(\nu_{0}^{R}+1\right) /\left(4 Q_{0}\right)$

$A_{1}^{\prime}=-\rho^{\prime} g X^{2} r_{0}^{2} / 2$

$b_{1}^{\prime}=-\left(1-\nu_{0}^{c}\right) \rho^{\prime} g X^{2} r_{0}^{2} / 4$

$c_{1}^{\prime}=r_{0}^{4} X^{4} \rho^{\prime} g\left(1-\nu_{0}^{c}\right) /\left(8 Q_{1}\right)$

$d_{1}^{\prime}=\rho^{\prime} g\left(X^{2} \nu_{0}^{c}+1\right) /\left(8 Q_{1}\right)$

$a_{2}^{\prime}=-3 \rho g(1-k) h\left(\nu_{0}^{R}-3\right)\left(2 X^{4}+X^{2}+1\right) /\left(4 Q_{2}\right)$

$b_{2}^{\prime}=\rho g(1-k) h\left(\nu_{0}^{R}-3\right)\left(3 X^{2}+1\right) /\left(4 r_{0}^{2} Q_{2}\right)$

$c_{2}^{\prime}=-\rho g(1-k) h r_{0}^{4}\left(\nu_{0}^{R}-3\right) X^{4}\left(X^{2}+3\right) /\left(4 Q_{2}\right)$

$d_{2}^{\prime}=3 \rho g(1-k) h r_{0}^{2}\left(\nu_{0}^{R}-3\right) X^{2}\left(X^{4}+X^{2}+2\right) /\left(4 Q_{2}\right)$

$a_{3}^{\prime}=-\rho^{\prime} g / 24$

$+\rho g(1-k)\left(\nu_{0}^{R}-3\right)\left(3 X^{6}+X^{4}+X^{2}+1\right) /\left(4 Q_{3}\right)$

$$
\begin{aligned}
b_{3}^{\prime}= & -\rho g(1-k)\left(\nu_{0}^{R}-3\right)\left(4 X^{4}+X^{2}+1\right) /\left(8 r_{0}^{2} Q_{3}\right) \\
c_{3}^{\prime}= & \rho g(1-k) r_{0}^{6}\left(\nu_{0}^{R}-3\right) X^{6}\left(X^{4}+X^{2}+4\right) /\left(8 Q_{3}\right) \\
d_{3}^{\prime}= & -\rho g(1-k) r_{0}^{4}\left(\nu_{0}^{R}-3\right) X^{4}\left(X^{6}+X^{4}+X^{2}+3\right) /\left(4 Q_{3}\right) \\
S_{2}= & {\left[e \left\{b_{1}^{\prime}\left(1-\nu_{0}^{c}\right) \ln r_{0}+c_{1}^{\prime}\left(1+\nu_{0}^{C}\right) / r_{0}^{2}\right.\right.} \\
& +d_{1}^{\prime}\left(1-3 \nu_{0}^{C}\right) r_{0}^{2}-2 A_{1}^{\prime} \ln r_{0} \\
& \left.\left.+\rho^{\prime} g r_{0}^{2}\left(3-\nu_{0}^{C}\right)\right\} / 8-c_{1}\left(1+\nu_{0}^{R}\right)\right] / r_{0}^{2}
\end{aligned}
$$

ただし

$$
\begin{aligned}
Q_{0}= & X^{2}\left(e \nu_{0}^{c}+e-\nu_{0}^{R}-1\right)-\left(e \nu_{0}^{c}-e-\nu_{0}^{R}-1\right) \\
Q_{1}= & X^{2}+1 \\
Q_{2}= & \left(X^{6}-3 X^{4}+3 X^{2}-1\right)\left(e \nu_{0}^{c}-5 e-\nu_{0}^{R}-5\right) \\
& -8 e\left(3 X^{4}+1\right) \\
Q_{3}= & \left(X^{10}+X^{8}-8 X^{6}+8 X^{4}-X^{2}-1\right) \\
& \cdot\left(e \nu_{0}^{c}-7 e-\nu_{0}^{R}+7\right)-12 e\left(6 X^{6}-2 X^{4}+X^{2}+1\right) \\
e= & E_{0}^{R} / E_{0}^{c}
\end{aligned}
$$

上記のポアソン比，ヤング係数または変形係数は平面 応力場に対応する值であるが， $\nu_{0}^{R} ， \nu_{0}^{c}$ ，をそれぞれ $\nu_{R} /$ $\left(1-\nu_{R}\right), \nu_{c} /\left(1-\nu_{c}\right)$, さらに $E_{0}^{R}, E_{0}^{c}$ をそれぞれ $E_{R} /(1-$ $\left.\nu_{R}^{2}\right), E_{c} /\left(1-\nu_{c}^{2}\right)$ に置き換えれば，平面ひずみ状態にお ける値となる.

ライニングに発生するトンネル軸方向単位幅当たりの 断面力はライニングに発生する応力をライニングの厚さ について積分すればよい. 単位幅当たりのモーメント,
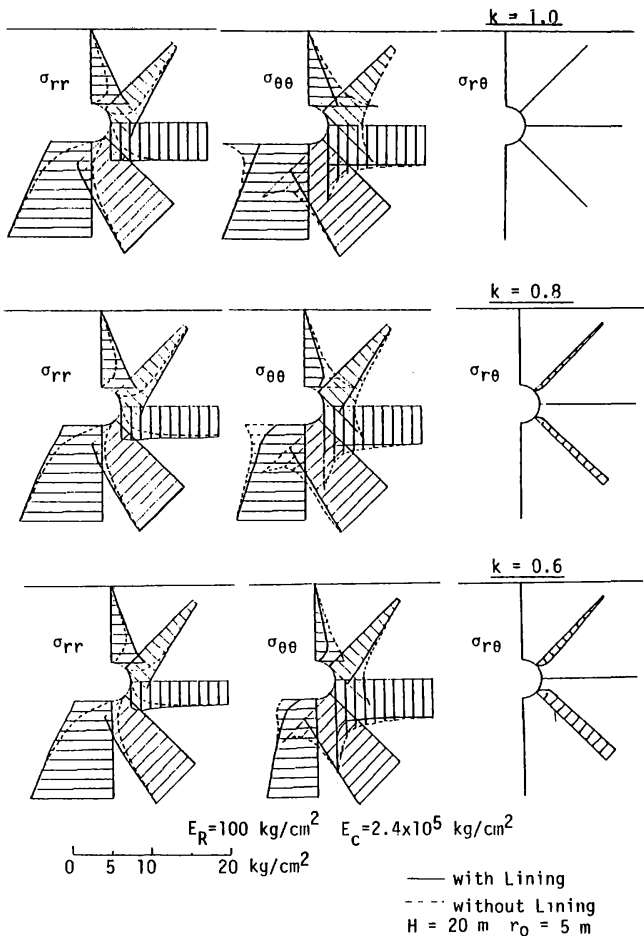

図一2 地山内の応力分布 


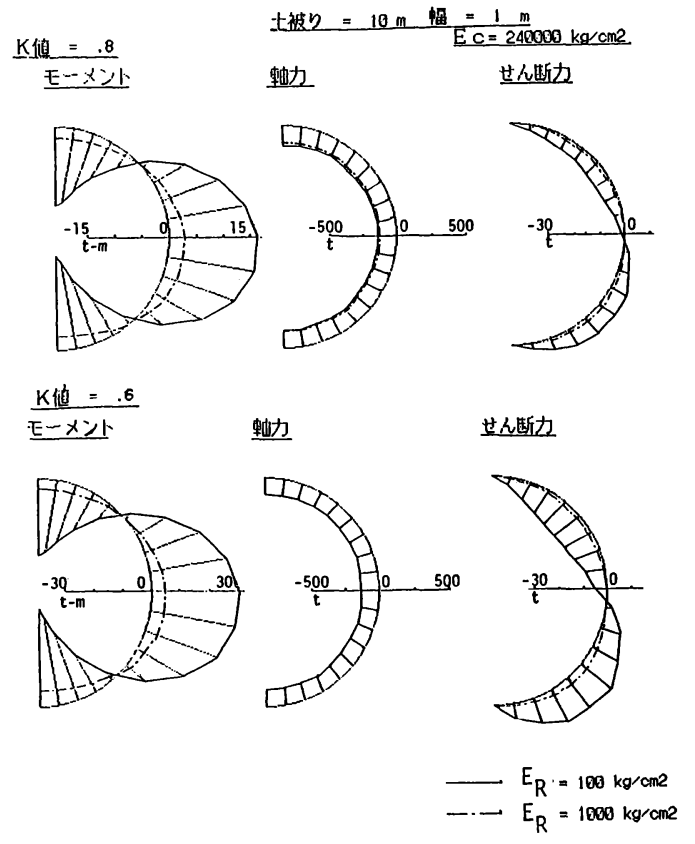

図一3 ライニングに発生する断面力 $(t=30 \mathrm{~cm}, h=15 \mathrm{~m})$

軸力およびせん断力をそれぞれ $M(\theta), N(\theta), S(\theta)$ で 表わすとすれば，それらは以下のように与えられる.

$$
\begin{aligned}
& M(\theta)=\int_{A}\left\{\sigma_{\theta \theta}^{c}-N(\theta) /\left(r_{0}-r_{1}\right)\right\} r d r \\
& N(\theta)=\int_{A} \sigma_{\theta \theta}^{c} d r \\
& S(\theta)=\int_{A} \sigma_{r \theta}^{c} d r
\end{aligned}
$$

\section{3. 地山の応力分布とライニングに働く断面力}

図一2 は側圧係数 $k$ がそれぞれ $1.0,0.8,0.6$ のとき, 地山に発生する応力 $\sigma_{r r}^{R}, \sigma_{\theta \theta}^{R}, \sigma_{r \theta}^{R}$ を示したものである. 土被りは $20 \mathrm{~m}$ とし, トンネルの半径は $5 \mathrm{~m}$, 土の単位 体積重量は $2.0 \mathrm{t} / \mathrm{m}^{3}$, また地山の変形係数は $E_{R}=100$ $\mathrm{kg} / \mathrm{cm}^{2}(9.8 \mathrm{MPa})$, ライニングのヤング係数は $E_{c}=$ $2.4 \times 10^{5} \mathrm{~kg} / \mathrm{cm}^{2}(23.5 \mathrm{GPa})$ にとっている. 実線はラ イニングを施工した状態を表わしており，破線は掘削後 ライニングを施工せずに十分時間が経過した状態を表わ している. シールドトンネルの場合には山岳トンネルと 異なり ${ }^{1), 21}$, ライニングのヤング係数に対する地山の変 形係数の比 $E_{R} / E_{c}$ が極端に低くなるため（図の場合で $\left.4 \times 10^{-4}\right)$, 裏込め注入材の適切な施工によって掘削後地 山とライニングの間に空隙が発生しない限り, 地山に発 生する直応力は掘削前の状態に近い. その結果, ライ二 ングによる効果が著しく大きく, 直応力に関しては掘削 後も掘削前の地山にほぼ近い状態を保つことができる. しかし，ライニングと地山の境界でせん断応力が 0 とな

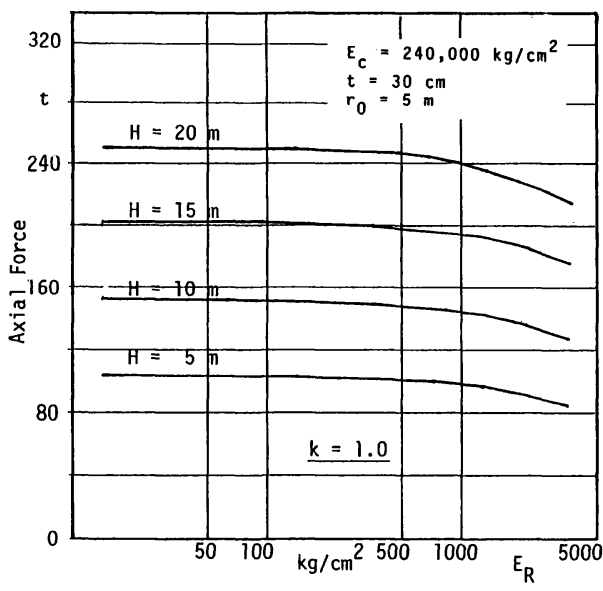

(a) $k=1.0$

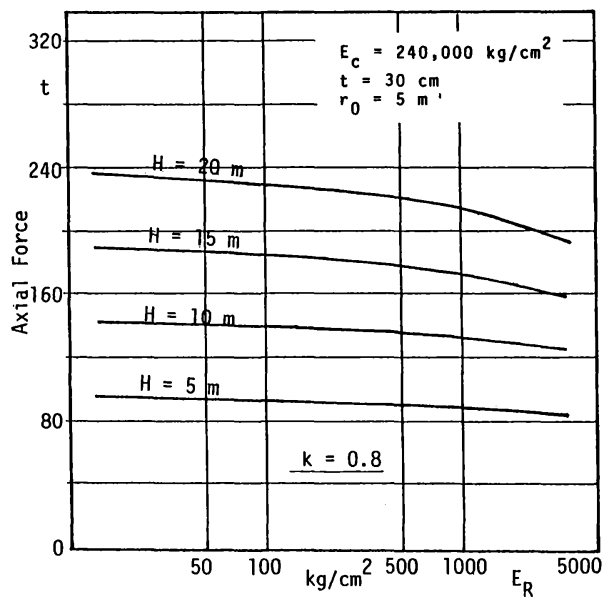

(b) $\quad k=0.8$

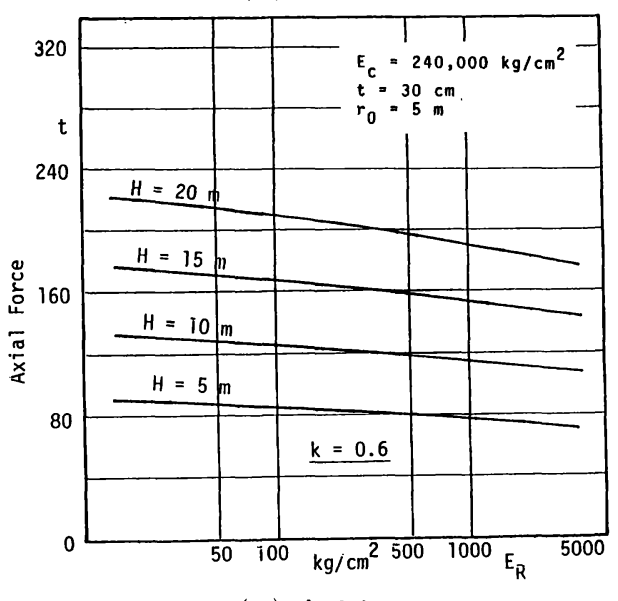

(c) $k=0.6$

図一4 軸力と地山の変形係数

る場合には必ずしもこの事実は地山が塑性化しないこと にはつながらない。

図一3 はライニングに発生するモーメント, 軸力, せ 
ん断力の一例を示したものである. 図の上側は側圧係数 が $k=0.8$ の場合を, 下側は $k=0.6$ の場合を示してい る.ここではライニングの厚さ $t$ を $30 \mathrm{~cm}$, ヤング係数 $E_{c}$ を $2.4 \times 10^{5} \mathrm{~kg} / \mathrm{cm}^{2}(23.5 \mathrm{GPa})$ にとっている. 図中, 実線は地山の変形係数 $E_{R}$ を $100 \mathrm{~kg} / \mathrm{cm}^{2}(9.8 \mathrm{MPa})$, 一点鎖線は $1000 \mathrm{~kg} / \mathrm{cm}^{2}(98 \mathrm{MPa})$ とした場合である. 側圧係数 $k$ が 1 のときはモーメントおよびせん断力は ほとんど発生せず, 軸力は $k=0.8, k=0.6$ の場合とほ ぼ一致するため，ここでは示していない．土被りが一定 であれば, 側圧係数が 1 より小さくなるにつれて, モ一 メントとせん断力は増加するが, 軸力はほとんど変化す ることはない，せん断力の絶対値はきわめて小さく，地 山が塑性化しないかぎりセグメント継手がモーメントの 伝達のためにあることがわかる.

より一般的な傾向を知るために, 軸力やモーメントに 対する側圧係数 $k$, 土被り $H$, 地山の変形係数 $E_{R}$ の関

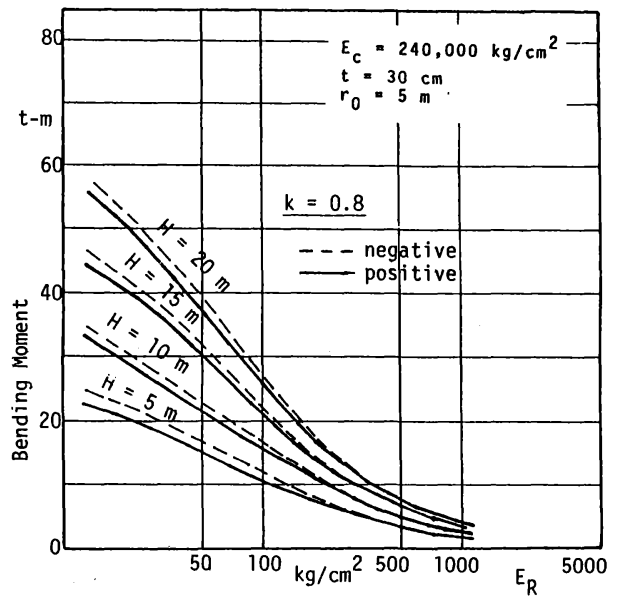

(a) $k=0.8$

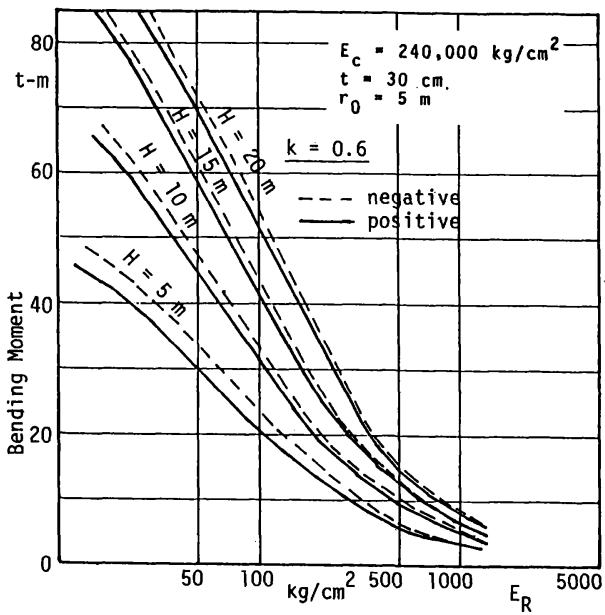

(b) $k=0.6$
係を求め, 図一4(a), (b), (c), 図一5(a), (b) に示 した．図一4に示すように，ライニングに働く軸力は地 山の変形係数 $E_{\mathrm{R}}$ が変化しても, 変化は少ないので, 地 山の変形係数が低いときの値をもって設計すれば, 妥当 な安全側の設計が可能である.これに対して, 図一5に 示すモーメントは, 地山の変形係数 $E_{R}$ の増大とともに 急速に減少している. 軸力の変動が側圧係数や地山の変 形係数に影響されにくいことを考えると，ライニングの 断面が力学的には主にモーメントの大きさによって左右 されることを物語っている，緩み土圧ではなく，鉛直土 圧を地表面からとった場合には，シールドトンネルに働 く断面力の現行の設計法は6), 地山の変形係数が低い值 をとるときと一致している.

上記の計算は地山が弾性状態にあって, 常に安定であ ると仮定して行った計算結果である. 側圧係数 $k$, 変形 係数 $E_{R}$, 土被り $H$ の組合せによっては, 掘削後地山が 塑性化することも考えられるから，図一2〜6の利用に あたっては，以下に述べるように地山が塑性化しない限 界を把握し, その枠内で用いる必要がある.

\section{4. コンクリートライニング施工後のトンネル の安定性}

前節で述べたように，シールドトンネルの設計では， ライニングに作用する断面力に対して安全な断面寸法の 決定のほかに, 地山を塑性化させないための条件もあわ せて検討しなければならない。

地山の安定性を調べるには，地山が蓄えることができ る最大形状弾性ひずみエネルギーと, 地山に発生する形 状弾性ひずみエネルギーを比較すればよい文．地山に発 生する形状弾性ひずみエネルギー $U_{s}$ は次式によって求 めることができる.

$$
U_{s}(k, \theta)=\frac{1}{6 G}\left[\left(\sigma_{r r}^{(R)}+\sigma_{\theta \theta}^{(R)}\right)^{2}-3 \sigma_{r r}^{(R)} \sigma_{\theta \theta}^{(R)}+3 \sigma_{r \theta}^{(R) 2}\right] \cdots
$$

ここでは山岳トンネルと違って比較的浅いトンネルを対 象としているから，地山の材料定数として一軸圧縮強度 $\sigma_{y}$ よりは, 粘着力 $c$ や内部摩擦角 $\phi$ を用いる方が都合 がよい. そこで, 最大形状弾性ひずみエネルギーの算定 には Drucker-Prager の降伏条件を用いることにする11. Von Mises の降伏条件の場合には, 以下の式において, 内部摩擦角 $\phi$ を $0^{\circ}$ にとり, 粘着力比 $2 \mathrm{c} / \mathrm{s}$ を地山強度 比 $\sigma_{y} / s$ に読み換えればよい1). ただしここで $s=\rho g(h$ -y）であり，c は粘着力を表わしている. DruckerPrager の降伏条件による最大形状弾性ひずみエネル ギーは以下の式で与えられる.

$$
\bar{U}_{s}=\frac{s^{2}}{6 G}\left[\frac{\left\{2\left(\sigma_{r r}^{(R)}+\sigma_{\theta \theta}^{(R)}\right) / s \cdot \sin \phi+3(2 c / s) \cdot \cos \phi\right\}^{2}}{(3-\sin \phi)^{2}}\right]
$$


これら $2 つ の$ 形状弾性ひずみエネルギーの間に, 常に 次の関係が満たされるならば, 円孔周辺の地山は塑性化 . することはない.

$$
\bar{U}_{s}>U_{s}(k, \theta) \cdots
$$

しかし, 式 (17) の形では, 単に地山が弾性状態にとど まるか, 塑性化するかの判定を知るのみで, 地山の安定 性を定量化することができない，そこでここでは，以下 に示す安全率を用いて, 塑性化の程度を定量化する.

$$
f=\sqrt{\left\{\bar{U}_{s}+\left(U_{s}^{(2)}-U_{s}^{(3)}\right)\right\} / U_{s}^{(2)}}
$$

上式で $\bar{U}_{s}$ は式 (16) で与えられる最大形状弾性ひずみ エネルギーである. $U_{s}^{(2)}$ は掘削のみでライニングを施工 しないときに地山に発生する形状弾性ひずみエネルギー である. $U_{s}^{(2)}$ の值の求め方はライニング厚 $t$ を 0 とおい て求めた応力から, 式 (15) のエネルギーを導いて決定 すればよい. それに対して， $U_{s}^{(3)}$ は，ライニングを施工 したとき地山に発生する形状弾性ひずみエネルギーを表 わしている. したがって, 式 (18) において $U_{s}^{(2)}-U_{s}^{(3)}$ はライニングの施工によって改善される形状弾性ひずみ エネルギーである. 式（18）の安全率の值が 1 以上であ れば, その結果は式 (17) に一致する. また, 安全率が 1 以下であれば地山が塑性化することを表わしている.

図一6(a), (b) は地山内の各地点でこの安全率がご のようになっているかを等高線で示した計算結果の一例
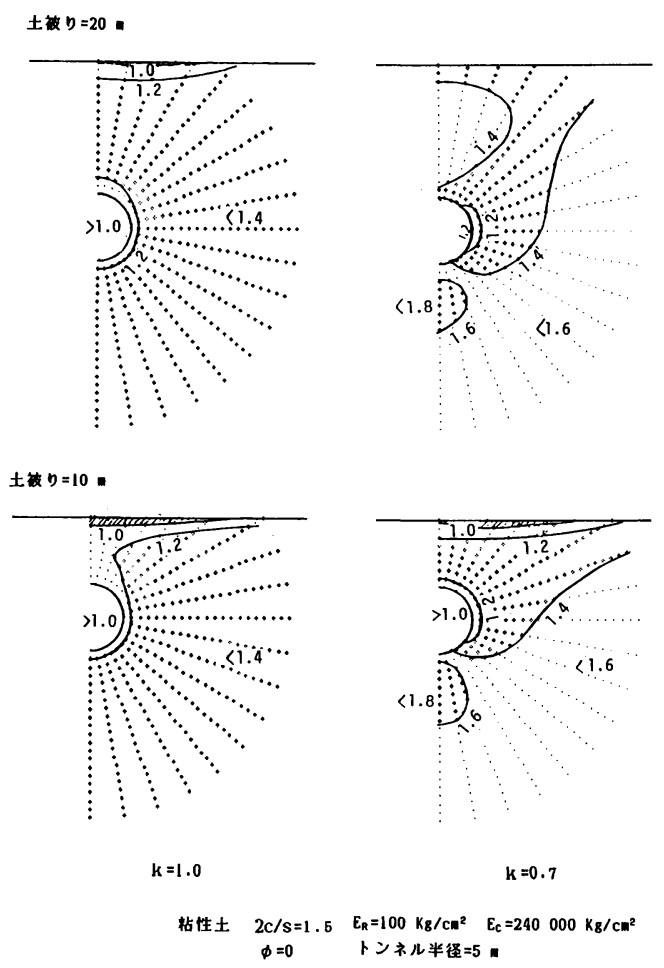

（a ）粘性土の場合
である. ライニング厚は $t=30 \mathrm{~cm}$ にとり, ライニング のヤング係数は $E_{c}=2.4 \times 10^{5} \mathrm{~kg} / \mathrm{cm}^{2}(23.5 \mathrm{GPa})$ とお いている. それぞれ図一6(a) は粘性土（ $2 \mathrm{c} / \mathrm{s}=1.5$, $\left.\phi=0^{\circ}\right)$, 図一6(b) は砂質土 $\left(2 \mathrm{c} / s=0, \phi=40^{\circ}\right)$ の一 例である. 図の上側は土被り $20 \mathrm{~m}$, 下側は土被り $10 \mathrm{~m}$ の場合である. また, 図の左半分は側圧係数 $k=1.0$ の 場合, 右半分は $k=0.7$ の場合である. トンネルの外径 は $5 \mathrm{~m}$, 地山の変形係数 $E_{R}=100 \mathrm{~kg} / \mathrm{cm}^{2}(9.8 \mathrm{MPa})$ にとっている. 塑性化する領域は斜線で示されている.

側圧係数 $k=1$ では与えられた条件のもとで粘性土, 砂質土ともに, 地表面が塑性化する. トンネル周壁の領 域で粘性土では塑性化しないものの, やや安全率が低下 している. 一方側圧係数 $k=0.7$ の場合には, 粘性土で は周辺の地山の状態が複雑な様相を示す. トンネル下端 部で比較的安定であるのに対し, 側壁, 天端近くの地山 が不安定となる．砂質土では天端での領域が塑性化して おり，土被りが $10 \mathrm{~m}$ の場合には $20 \mathrm{~m}$ の場合に対して， 地表面の塑性領域と天端の塑性領域がつながっている. これらの傾向は, 地山の条件によって異なり, 粘着力比 $2 c / s$ や内部摩擦角 $\phi$ の值によって変化する. したがっ て, 図一6は比較的不安定な条件下における一例にすぎ ないが, 土被りが浅いトンネルの特徴として, 重力の影 響が大きく, 下端部付近と比べて天端から地表面にかけ
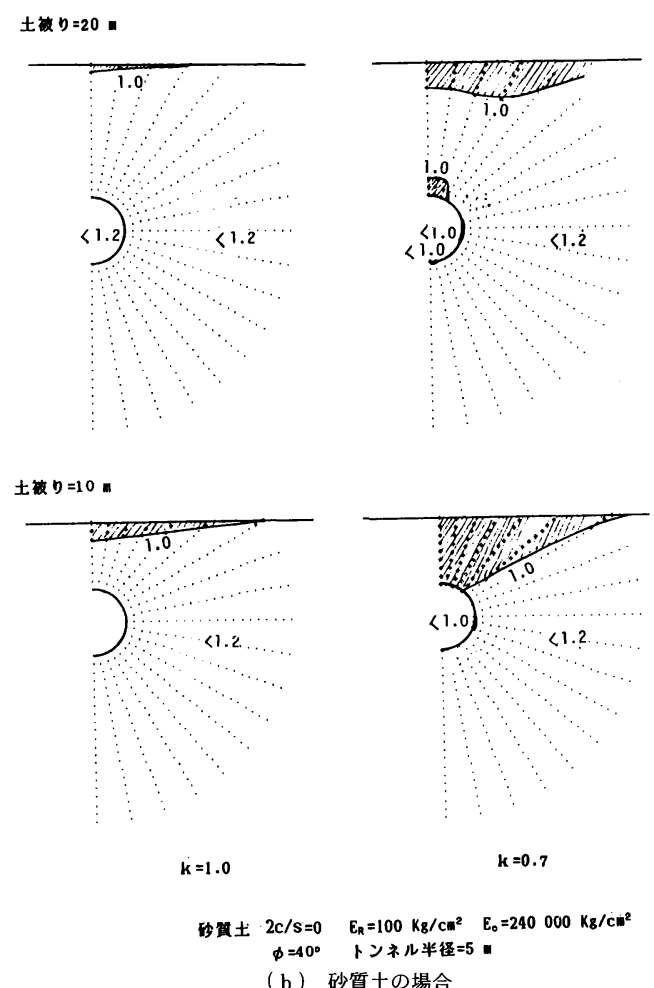

（b）砂質土の場合 
ての領域が不安定になる傾向がある.

\section{5. 地下水の影響を考慮したシールドトンネル の安定性}

地山内に間隙水圧が作用している場合，平均的にみて 静水圧とみなすことができるならば，水圧は等方性の応 力であるから偏差応力に影響を与えることはない。この 事実から, 間隙水圧が存在する場合, 形状弾性ひずみ工 ネルギーの計算に用いる応力は, 地山に発生する応力か らこの水圧による静水圧の成分を差し引いた有効応力成 分になる. Drucker-Prager や Mohr-Coulomb の降伏条 件では，この有効応力を用いて平均応力を求めるため, 地下水が作用する場合には平均応力は減少し, 地山に蓄 えられる最大形状弾性ひずみエネルギーが小さくなる. しかし，地山に発生する形状弾性ひずみエネルギーにも 有効応力に関しては同様なことがあてはまる．その結果 上述の 2 つの形状弾性ひずみエネルギー相互の大小関係 から定まる地山の安定性が, 必ずしも水圧が作用しても, 悪くなるとは限らない.

地下水の影響を考慮するとき, 地下水面下の土の重量 を水中重量にとると, 無限遠での境界条件は以下のよう になる.

$$
\begin{aligned}
& \sigma_{x x}=-k\left\{\rho\left(h-h_{w}\right)-\left(\rho_{\text {sat }}-\rho_{w}\right)\left(h_{w}-r \sin \theta\right)\right\} g \\
& \sigma_{y y}=-\left\{\rho\left(h-h_{w}\right)-\left(\rho_{\text {sat }}-\rho_{w}\right)\left(h_{w}-r \sin \theta\right)\right\} g \\
& \sigma_{x y}=0
\end{aligned}
$$

ただし $\rho$ は地下水面より上の土の湿潤密度， $\rho_{\text {sat }}$ は地 下水面下の土の飽和湿潤密度, $\rho_{w}$ は地下水の密度, $h$ はトンネル中心から地表面までの距離, $h_{w}$ はトンネル 中心から地下水面までの距離である. 式（19）の境界条 件を用いてこれまでと同様の解析を行うと，4. の地下 水の影響を考慮しない場合と同様に，応力と変位を求め ることができる. 一例として地下水面が地表面の位置に あるとき, ライニングと地山の境界 $\left(r=r_{0}\right)$ での応力 を示せば，次式のようになる.

$$
\begin{aligned}
\sigma_{r r}\left(r_{0}, \theta\right)= & \frac{\left\{s(1+k)+2 h_{w} \rho_{w} g\right\} \Delta_{2} e}{2 \Delta_{1}}-\frac{s(1+k)}{2} \\
& -\rho_{w} r_{0} \sin \theta \\
\sigma_{\theta \theta}\left(r_{0}, \theta\right)= & -\frac{\left\{s(1+k)+2 h_{w} \rho_{w} g\right\} \Delta_{2} e}{2 \Delta_{1}}+\frac{s(1+k)}{2} \\
& +\frac{r_{0}\left\{2 k\left(\rho-\rho_{w}\right)\left(1-\nu_{R}\right)+\left(1-2 \nu_{R}\right)\left(\rho+2 \rho_{w} \delta\right)\right\}}{2\left(1-\nu_{R}\right)} \\
& \cdot \sin \theta-2\left(\rho g h_{1}+\left(\rho-\rho_{w}\right) h_{w}\right)(1-k) \cos 2 \theta \\
& +\left(\rho-\rho_{w}\right) r_{0}(1-k) \sin 3 \theta \\
\sigma_{r \theta}\left(r_{0}, \theta\right)= & 0
\end{aligned}
$$

$$
\begin{aligned}
& s=\left\{\left(\rho-\rho_{w}\right) h_{w}+\rho h_{1}\right\} g \\
& h_{1}=h-h_{w}, \quad \delta=t / r_{0} \\
& \Delta_{1}=\delta\left\{E_{R}\left(1+\nu_{c}\right) / E_{c}-\left(1+\nu_{R}\right)\right\}-E_{R}\left(1-\nu_{c}^{2}\right) / E_{c} \\
& \Delta_{2}=\delta /\left(1-\nu_{c}\right)-1 \\
& e=E_{R}\left(1-\nu_{c}^{2}\right) /\left\{E_{c}\left(1-\nu_{R}^{2}\right)\right\}
\end{aligned}
$$

図一7 は地下水面が地表面の位置にあるとき, 式 (18) に従って, 側圧係数 $k=1$ の場合の地山内の安全率を求 めたものである. 図の左側は粘性土 $(2 \mathrm{c} / \mathrm{s}=1.5, \phi=$ $\left.0^{\circ}\right)$ の場合を, 右側は砂質土 $\left(2 c / s=0, \phi=40^{\circ}\right)$ の 場合を示している。これを図一 6 に示す間隙水圧が作用 しない結果と比較すれば，粘性土では間隙水圧が作用す る場合の方がかえって安定になるのに対して, 砂質土の 場合ではより不安定になり, 天端から地表面にかけての 塑性化領域が大きくなっている.

図一7は特定の条件のもとでの結果であるが，図一8 (a)，(b) に側圧係数 $k=1$ の場合について地山が塑性 化する限界を示した. 図中, 実線は地下水がない場合で あり，一点鎖線は地下水面が地表面にある場合である. いずれも地山の条件がこれらの線の上側にある領域は, 線上に示された条件下でトンネル周辺の地山は塑性化す ることはない，これに対して，線の下側にある場合には トンネル周辺の地山の一部が塑性化することを表わして
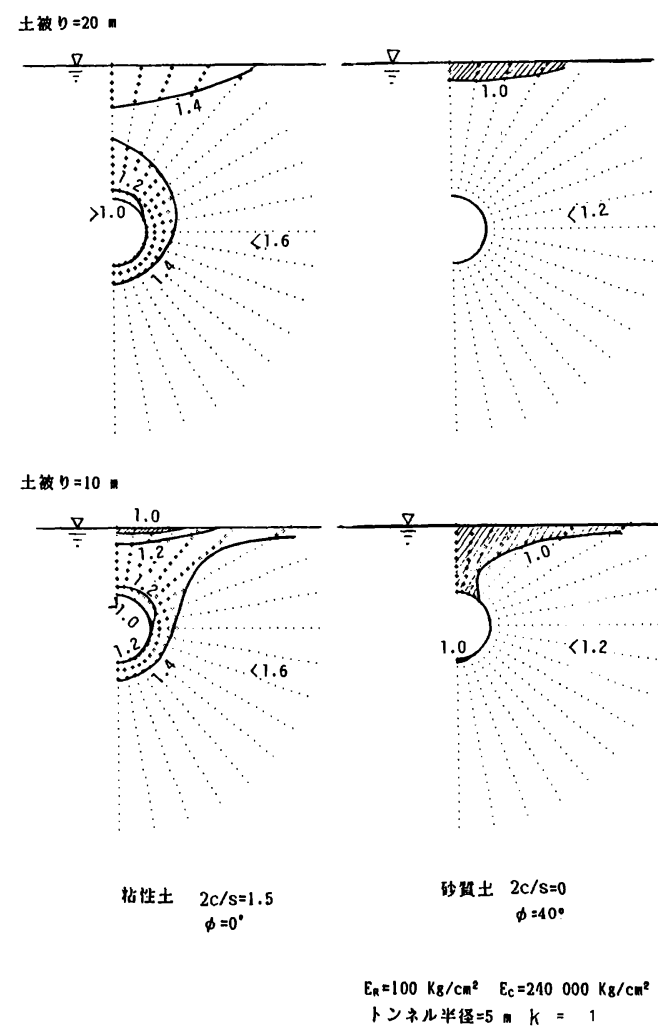

図一7間隙水圧作用下における地山の安定領域

ただし 


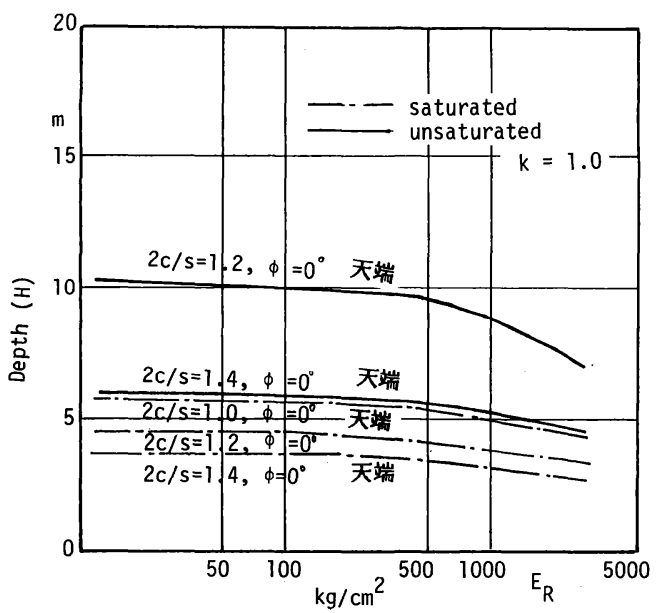

(a) 粘性土

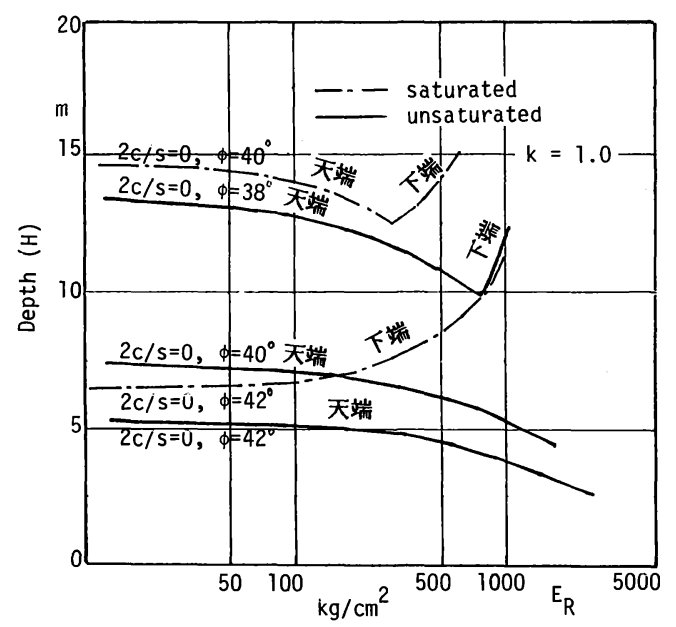

(b) 砂質土

図一8 地山が塑性化しないための限界

いる．線上に示す「天端」，「下端」の記述は最初に塑性 化が始まる箇所を示している.

一例として砂質土 (図一8 $(\mathrm{b}))$ の場合, 粘着力比 2 $c / s=0$, 内部摩擦角 $\phi=40^{\circ}$, 地山の変形係数 $E_{R}=100$ $\mathrm{kg} / \mathrm{cm}^{2}$ で土被り $H=10 \mathrm{~m}$ の条件下では, 間隙水圧が作 用するときには地山は塑性化するが，地下水がないとき には,塑性化しないということを読み取ることができる. ただし，地表面表層のごく一部は平均応力が 0 または 0 に近いため, 常に塑性領域が現われる.これらの図から 先にも述べたように，粘性土と砂質土では地下水に対す る傾向が異なり, 粘性土では地下水は安全側に作用する が，砂質土では危険側に作用することがわかる.

図一 9 は $k=0.8, E_{R}=100 \mathrm{kgf} / \mathrm{cm}^{2}(9.8 \mathrm{GPa}), E_{c}$ $=2.4 \times 10^{5} \mathrm{kgf} / \mathrm{cm}^{2}(23.5 \mathrm{GPa}), \quad \nu_{R}=0.3, \quad \nu_{c}=0.17$, $r_{0}=5 \mathrm{~m}, \quad t / r_{0}=0.06, \rho=2.0 \mathrm{t} / \mathrm{m}^{3}, \quad \rho_{w}=1.0 \mathrm{t} / \mathrm{m}^{3}, h$
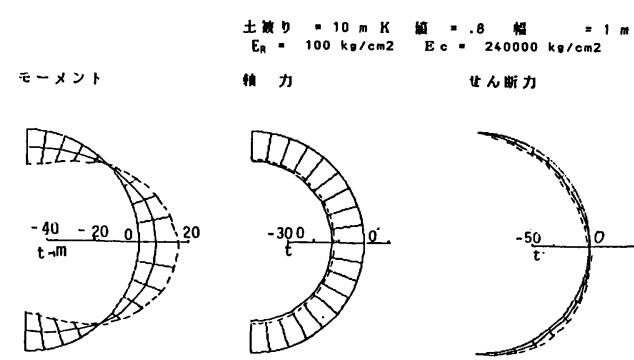

th $力$
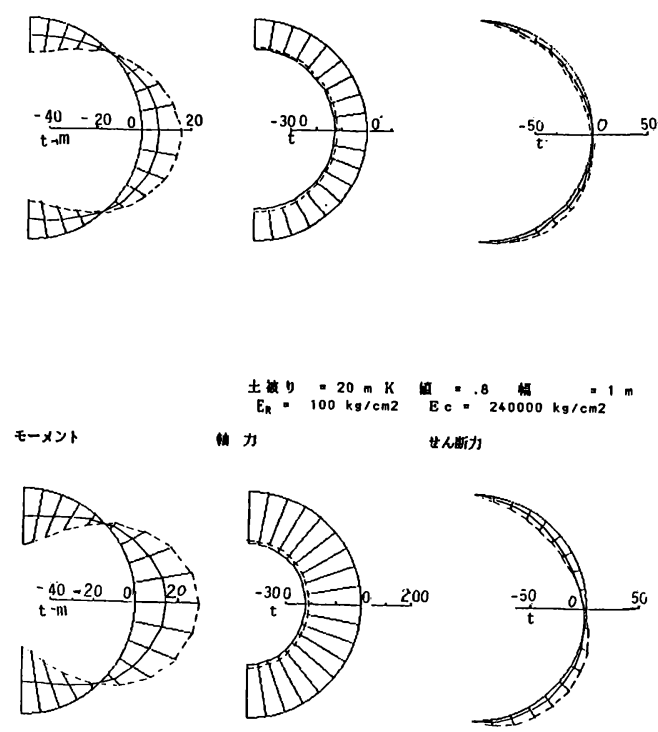

图一9間隙水圧作用下における断面力の分布

$=h_{w}$ としたときに，土被り $10 \mathrm{~m}$ と $20 \mathrm{~m}$ の場合のライ ニングに発生するモーメント, 軸力, せん断力を表わし たものである. 同時に同じ条件下で地下水が存在しない 場合の断面力も破線で表わしている. ライニングに作用 する応力は静水圧により近くなるので, モーメントやせ ん断力は間隙水圧のない場合と比べて，より小さな値と なっている。しかし，間隙水圧は作用するので，軸力は 地下水がない場合よりやや大きな值になる．地山の安定 性やライニングの断面力に対する地下水の影響は, 地山 の条件によって左右されるので，いつも安全側になると は限らない。

図一10(a)，(b)，図一11に地下水がある場合のそれ ぞれ軸力, 曲げモーメントと地山の変形係数の関係を示 した.これらの図はそれぞれ図一 4 , 図一 5 と対応して いる. 軸力はほぼ同等の值となるのに対して, 曲げモー メントについては, 地下水が存在しない場合のほぼ $1 / 2$ の値となっている.

\section{6. 結 論}

本研究は, シールドトンネルの安定性を評価する手法 に関する提案である. 本論文によって得られた結論は以 下のようにまとめられる.

（1） シールドトンネル施工時の地山の安定性を, 地 山に生ずる形状弾性ひずみエネルギーと地山が蓄えるこ とができる最大形状弾性ひずみエネルギーの大小関係か ら判定する手法を提案した. 


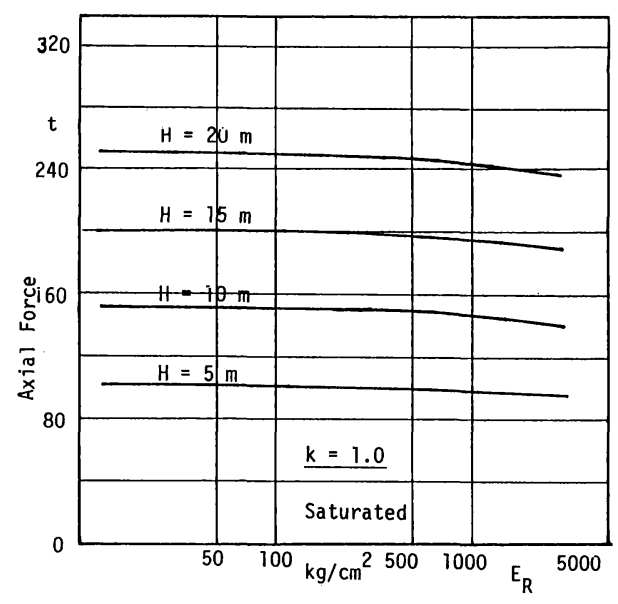

(a) 地下水面下 $k=1.0$

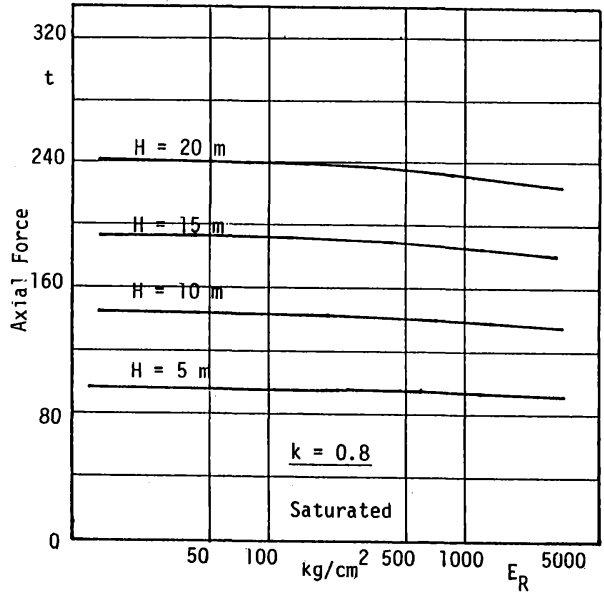

（b） 地下水面下 $k=0.8$

\section{図一10 軸力と地山の变形係数}

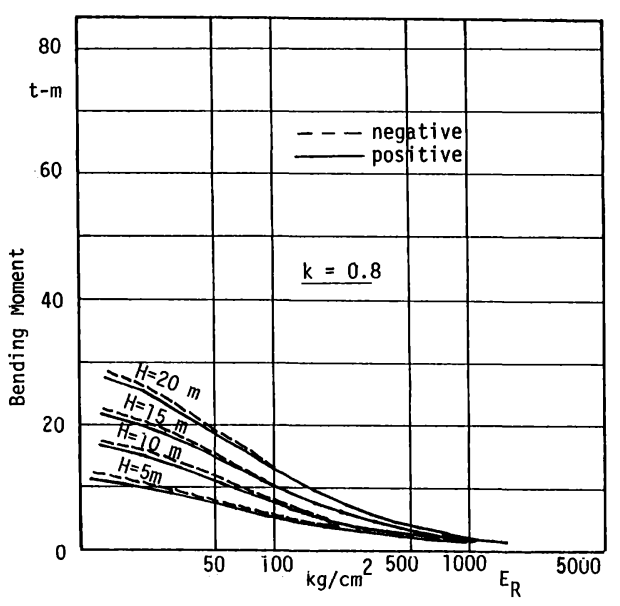

図一11 モーメントと地山の変形係数（地下水面下 $k=0.8 ）$

（2）トンネルのライニングに発生する曲げモーメン 卜は，地山の変形係数および側圧係数 $(0 \leqq k<1)$ が大 きくなるにつれて著しく減少するが，一方これらの特性 值に対する軸力はほとんど変化しない. シールドトンネ ルに働く断面力の現行の設計法は地山の変形係数が低い 值のときに一致し, 地山の変形係数が高いときには安全 側の設計になる.

（３）地下水面下にあるトンネルでは，地下水面がな いトンネルと比べてライニングに働く曲げモーメントは 著しく減少するものの, 軸力の増加はきわめて小さい.
地山の安定性については地山の条件と地下水面の位置に よってさまざまに変化するが,一般的な地下水面下にあ るトンネルでは, 粘性土ではより安全側に, 砂質土では より危険側になる.

\section{参 考 文 献}

1）西岡 隆・松本嘉司：形状弾性ひずみエネルギーによる トンネル周辺地山の安定解析, 土木学会論文集, 第 376 号, pp. 151 160, 1986. 12 .

2）松本嘉司・西岡 隆・鹿野正人：吹付けコンクリート之 ロックボルトを用いたトンネルの特性と事前設計方法, 土木学会論文集, 第 376 号, pp. 161 169, 1986.12.

3）松本嘉司・西岡 隆・佐野可寸志：土被りの浅いトンネ ルの事前設計方法, 土木学会論文集, 第 394 号, pp. 105 $\sim 114,1988.6$.

4） M. J. ボックス，D. デイビズ，W.H. スワン著（黒田 充訳) : 非線形最適化法の技法, 培風館.

5）今野 浩・山下 浩：非線形計画法, 日科技連, 1978.

6) 土木学会：トンネル標準示方書 (シールド編) ・同解説, 1986.

7) Mindlin, R. D. : Stress Distribution Around a Tunnel, Trans. ASCE, Vol. 105, 1940.

8）安蔵善之助：水平表面に接して 1 円孔を有つ重力体中の 応力に就いて, 九州大学工学部暉集, Vol.12, No. 3, 1937.

9）伊藤富雄 : 傾斜面下に掘ったトンネルの周辺応力につい て, 土木学会誌, 36-2, 1951.

（1988.8.1 • 受付） 